\title{
Improvement of bearing capacity of soil by using natural geotextile
}

\author{
B. Panigrahi ${ }^{*}$ and P. K. Pradhan
}

*Correspondence:

bobbypanigrahi1991@gmail. com

Civil Engg. Department,

Veer Surendra Sai University

of Technology, Burla,

Sambalpur 768 018, India

\begin{abstract}
An experimental study has been carried out to improve the bearing capacity of soils by using geotextile. In the present study geojute (gunny bags) is used as geotextile, whereas sand is used as soil media. This research presents the results of laboratory load tests on model square footings supported on reinforced sand beds. A total of 32 load tests are conducted to evaluate the effects of single layer reinforcement placed below square model footings. Parameters of testing programme of the research are the depth of reinforcement, the plan area of reinforcement and the footing size. The test results indicated that the maximum gain in ultimate bearing capacity (UBC) of footings on reinforced soil (by using geojute) is found to be increased by a factor of 3.37 as compared to soil without geojute. Also, the optimum size of reinforcement is found to be $3.5 \mathrm{~B} \times 3.5 \mathrm{~B}$ irrespective of the type of reinforcing materials used. The optimum placement position of geotextile is found to be $0.5 \mathrm{~B}$ from the base of the footing. At low settlement rates, the study on the values of $B C R$ reveals almost the same results with regard to optimum depth and size of reinforcement mentioned above. It is found that with increase in the settlement rate, BCR increases. Also, the improvement in bearing capacity is found to increase with increase in footing size.
\end{abstract}

Keywords: Foundation, Geojute, Geotextile, Reinforcement, Settlement, Ultimate bearing capacity

\section{Introduction}

Generally the placement of the foundation of the structure on the loose soil strata causes the structural damage. These loose soil strata have no capacity to sustain the structural load of the structures. As a result settlement and cracks are developed on the structures and structure will undergo collapse. So people choose the deep foundation to construct their structure in these loose soil strata. But sometimes the costs for the construction of structures are more due to the adoption of deep foundation. Hence, to avoid the above problems, the ground improvements are adopted. The use of geo synthetics is most common method for the improvement of ground. These geo synthetics are used as reinforcing agent to reinforce the soil strata, as a result the density and strength (bearing capacity) of the soil strata increased.

The term reinforced soil refers to a soil that has been strengthened by placement of reinforcing material within the soil mass in the form of strips, bars, sheets or grid (meshes). When load is applied to the reinforced soil mass, these materials resist tensile stresses which develop within the reinforced soil mass. When the tensile strength of an

(c) The Author(s) 2019. This article is distributed under the terms of the Creative Commons Attribution 4.0 International License (http://creativecommons.org/licenses/by/4.0/), which permits unrestricted use, distribution, and reproduction in any medium, provided you give appropriate credit to the original author(s) and the source, provide a link to the Creative Commons license, and indicate if changes were made. 
element is low, it can break or yield and become ineffective. If the tensile strength is adequate but its extension under stress is high, then the soil may show large movement or settlement because of the inadequate stiffness of the soil-reinforcement system.

Most of the studies are on strip or circular footings in spite of the fact that the rectangular and square footings are far more common in practice. The resting of square footings on the reinforced soils are studied by very few researchers like Akinmusuru and Akinbolade [2], Omar et al. [22], Adams and Collin [1], Ghazavi and Lavasan [14], Latha and Somwanshi [19], Kumar and Kaur [18], Lavasan and Ghazavi [20], Farsakh et al. [12] and Ronad [27]. Very few of the earlier researchers studied the difference in the effect of reinforcement for different footing shapes. Omar et al. [22] studied the effect of geogrid reinforcement for both strip and square footings resting on sand.

The favorable use of reinforcement materials like metal strips and geosynthetics to increase the bearing capacity of sand has been clearly traditional. Extensive research has been carried out by several researchers like Binquet and Lee [4, 5], Fragaszy and Lawton [13], Huang and Tatsuoka [15], Khing et al. [17], Yetimoglu et al. [34], Shin and Das [31], Dash et al. [11], Sitharam and Sireesh [32] and Patra et al. [23] to understand the role of reinforcement materials in improving the bearing capacity of foundation soils. From this study, it is concluded that the extent of effective reinforcement zone and the optimum width of the reinforcing layers are less for square footings compared to strip footings. More studies are needed in this direction to establish precise design procedures for geotextile reinforced square footings (RSF) in field.

Geo textile reinforcements are effectively used as a construction material to increase the bearing capacity and reduce the settlement of foundation resting on weak or poor soils. It can be used for many geotechnical constructions like foundations, retaining walls, embankments etc. Geo textiles are permeable fabrics which, when used in association with soil, have the ability to separate, filter, reinforce, protect or drain. As the use of geotextile fabrics has expanded there has been the introduction of geotextile composites and the development of products such as geogrids and meshes. Overall these materials are referred to as geotextiles and related products.

Geotextiles are broadly classified as natural or synthetic geotextiles depending upon the material of their composition. Geojute and coir nets are the commonly used biodegradeable natural geotextiles, whereas geotextiles made from synthetic polymer materials are the permanent and not biodegradable. Geojute is derived from jute plants grown mostly in India and Bangladesh. In recent years attempts are being taken to use jute geotextile (JGT) in many civil engineering applications.

Ranganathan [24] presented the development and potential of JCT and reported that once a road has been fully constructed and is in use, the geotextile becomes superfluous and hence the biodegradability of jute does not pose problems for this end use. Rao and Balan [25] reported that tensile strength of JGT embedded in soil would be negligible after 3-4 months. Rao and Vensiri [26] reported successful performance of an embankment over soft clay with JGT as a reinforcing layer at the base of the embankment. He concluded that aging of soil improves the overall performance of reinforced bed in spite of reduction in tensile strength of JGT. Sahu et al. [30] studied the behavior of Geojute reinforced in soil bed under cyclic loading. They observed that overall performance of pavement is not impaired even after complete biodegradation of Geojute. Jadhav and 
Damgir [16] successfully used jute geotextile JGT for reinforcement of soil to improve bearing capacity.

In order to improve the durability of JGT, a good number of investigations have been carried out. Macaulay [21] evaluated the influence of alkali treatment of jute fabrics reinforced epoxy composite, which concludes that improving the fibre-matrix adhesion that generally results in an increased tensile, flexural and impact properties of jute-epoxy composite compared to untreated fabric. The experimental results obtained in the above study have confirmed the work done by Rong et al. [28, 29] and Cao et al. [7]. A jutebased product may not last long enough when subjected to elements of nature due its bio-degradability. Banerjee and Ghosh [3] studied the mechanical behavior of jute in asphaltic medium upon hygral treatment and enzyme treatment simulating microbial attack which reveals that hygral treatment of even a 6-month period is ineffective in damaging the jute-asphalt interface and the encased jute because, asphalt acts as protector for jute against microbial attack. Further, it is observed that the use of jute geotextile as reinforcement material in soil is cost effective and technically viable, even though the jute is biodegradable in nature [8-10].

A number of laboratory test results and a few field test results have been published that is related to the ultimate and allowable bearing capacity of shallow foundations supported by geotextile reinforced sand and clay. Vidal [33] of France introduced the reinforcing mechanism to improve the bearing capacity of soil. However, the basic principles underlying reinforced soil is not completely investigated till dated. However, a very few research works are available on bearing capacity improvement using geojute reinforcement.

Hence, in the present study an attempt has been made to study the improvement in the bearing capacity of soil (sand) by using locally available geo jute (natural geo textile) as reinforcement.

\section{Objectives of the present study}

The aim of present work is to study the behavior of reinforced sand by using jute geotextile as reinforcement. The scope of the present study is

i. To determine the load settlement behavior without geotextile and with geotextile.

ii. To determine the optimum depth and optimum size of reinforcement.

iii. To evaluate the improvement in bearing capacity of reinforced soil.

\section{Materials used}

To study the ultimate bearing capacity of reinforced sand, sand is collected from the Mahanadi river at Sambalpur, Odisha whereas, geojute is collected from the local market.

\section{Sand}

The Sand is collected from the Mahanadi river bed at Sambalpur, Odisha. The collected sand is washed and cleaned to make it free from organic matters. Then the sand is oven dried and properly sieved to get the required grading. Dry sand is passed through the IS 
Table 1 Geotechnical properties of sand

\begin{tabular}{lc}
\hline Properties & Sand \\
\hline $\mathrm{D}_{10}(\mathrm{~mm})$ & 0.28 \\
$\mathrm{D}_{30}(\mathrm{~mm})$ & 0.37 \\
$\mathrm{D}_{60}(\mathrm{~mm})$ & 0.68 \\
Coefficient of uniformity $\left(\mathrm{C}_{\mathrm{u}}\right)$ & 2.42 \\
Coefficient of curvature $\left(\mathrm{C}_{\mathrm{c}}\right)$ & 0.71 \\
Bulk unit weight $\left(\mathrm{g}_{d}\right)$ in dry condition $\left(\mathrm{kN} / \mathrm{m}^{3}\right)$ & 15.9 \\
Maximum unit weight $\left(\mathrm{g}_{\mathrm{d}(\max )}\right)$ in compacted condition $\left(\mathrm{kN} / \mathrm{m}^{3}\right)$ & 16.7 \\
Minimum unit weight $\left(g_{\mathrm{d}(\min )}\right)$ in loose condition $\left(\mathrm{kN} / \mathrm{m}^{3}\right)$ & 14.8 \\
Maximum void ratio $\left(\mathrm{e}_{\max }\right)$ & 0.77 \\
Minimum void ratio $\left(\mathrm{e}_{\min }\right)$ & 0.57 \\
Relative density $\left(\mathrm{I}_{\mathrm{d}}\right)(\%)$ & 61.92 \\
Specific gravity & 2.62 \\
Free swelling index $(\%)$ & 0 \\
Shear strength & \\
$c(\mathrm{kPa})$ & 0 \\
$\varphi($ degree $)$ & $36^{\circ} 30^{\prime}$ \\
\hline
\end{tabular}

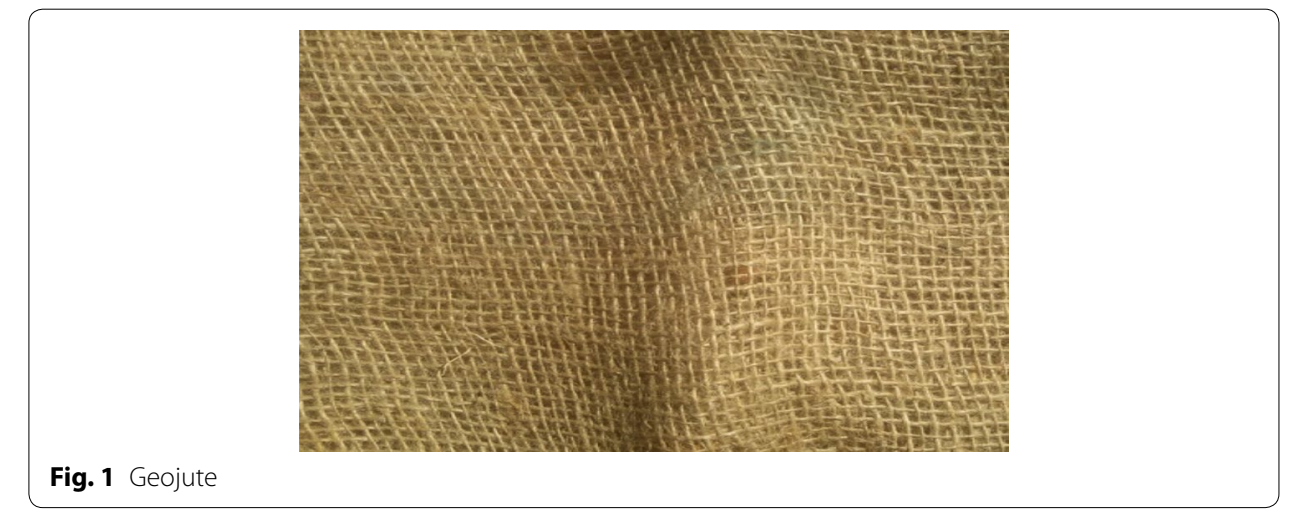

sieve of $2 \mathrm{~mm}$ and retained in 75 micron IS sieve. As per Bureau of Indian Standards: [6] IS 1498, the sand is classified as poorly graded sand (SP). The specific gravity (G) of sand is found to be 2.62. The details geotechnical properties of sand are reported in Table 1 .

\section{Geojute}

In the present study geojute (Fig. 1) is used as geotextile. This geojute is prepared from the jute gunny bags which are collected from the availability of local market. From the jute gunny bags, required size of cut piece of geojute is prepared. The thickness of each strand of jute thread used in the fabric is approximately $1.0 \mathrm{~mm}$ and tensile strength 2.4 $\mathrm{kN} / \mathrm{m}$.

\section{Experimental programme}

Based on the objectives of the present study, a detail experimental programme is prepared to study the improvement of bearing capacity of soil by using geojute (geotextile). A laboratory model is prepared to study the bearing capacity of reinforced soil 


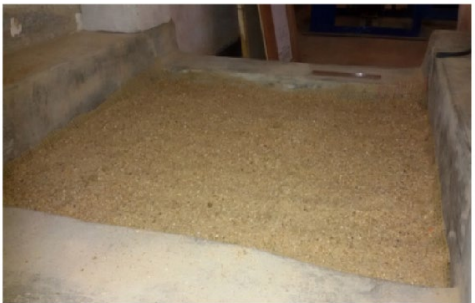

a Test tank with sand bed

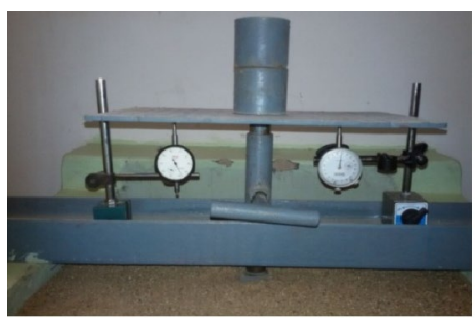

b Experimental set up of load test
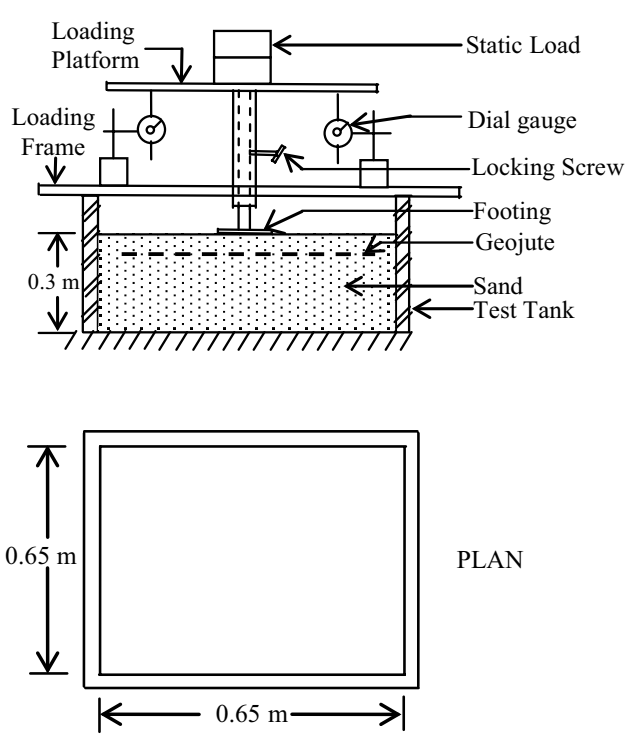

PLAN

Fig. 2 Experimental set up

(sand-geo jute layer). According to the experimental programme, different sizes of geojutes $(1 \mathrm{~B} \times 1 \mathrm{~B}, 1.5 \mathrm{~B} \times 1.5 \mathrm{~B}, 2 \mathrm{~B} \times 2 \mathrm{~B}, 2.5 \mathrm{~B} \times 2.5 \mathrm{~B}, 3 \mathrm{~B} \times 3 \mathrm{~B}, 3.5 \mathrm{~B} \times 3.5 \mathrm{~B}$ and $4 \mathrm{~B} \times 4 \mathrm{~B})$ are used to reinforce the sand layers. In the sand layers, geojutes are placed at $0.25 \mathrm{~B}, 0.5 \mathrm{~B}$, $0.75 \mathrm{~B}, 1.0 \mathrm{~B}, 1.25 \mathrm{~B}, 1.5 \mathrm{~B}, 1.75 \mathrm{~B}$ and $2.0 \mathrm{~B}$ depth, whereas $\mathrm{B}$ is the width of the footings. Here two types of model square footings i.e., $50 \mathrm{~mm} \times 50 \mathrm{~mm}$ and $75 \mathrm{~mm} \times 75 \mathrm{~mm}$ are used.

\section{Test bed preparation}

A brick masonry tank of size $0.65 \mathrm{~m} \times 0.65 \mathrm{~m} \times 0.3 \mathrm{~m}$ is constructed in the laboratory for the test purpose. The size of the tank is so decided that the failure zones developed during tests on model footings are not restricted due to presence of the sides and bottom of the tank. Then the test bed is prepared in the tank by using sand with or without geo jute (Fig. 2a). At first, the volume of the test tank is calculated by measuring the inside dimensions of the tank accurately. As per the volume of the tank, the required quantity of dry sand is taken by considering the unit weight of sand as $15.9 \mathrm{kN} / \mathrm{m}^{3}$. The above dry sand is poured in the tank through funnel in such a manner that the tip of the funnel remained at a height of $10 \mathrm{~cm}$ above the sand surface. This is done to attain a uniform density of sand medium inside the tank. During pouring, the funnel is moved spirally from the edge towards the center of the tank. After completely filling of the tank, the top surface of the sand is made smooth by a straight edge. The horizontality of the top surface of the sand is checked by means of a spirit level.

For test with reinforced soil bed, the reinforcing material such as geo jute is placed at the required depth and the tank is filled up with sand with the help of the funnel as described above. Before placing the geo jute (reinforcing material), the sand surface at the depth is leveled by means of a straight edge. Care is taken to maintain the 


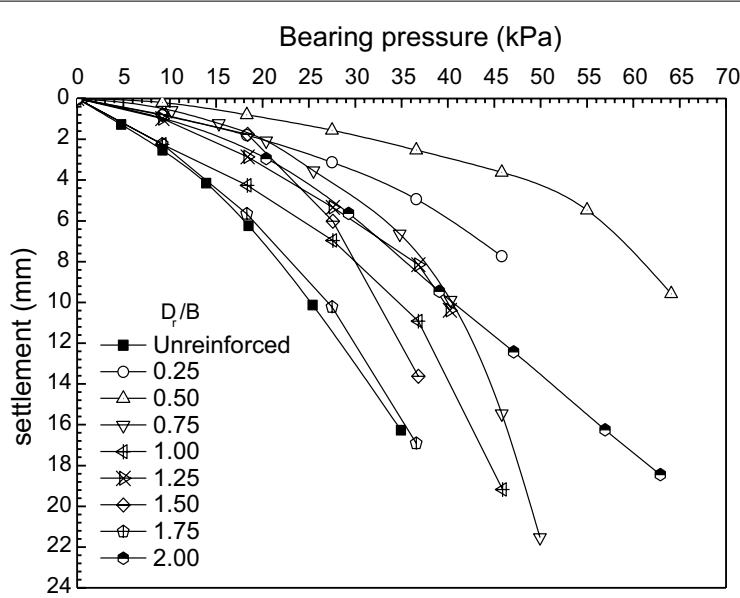

Fig. 3 Bearing pressure-settlement behavior of $50 \mathrm{~mm}$ square model footing on geojute reinforced sand

horizontality of the surface. For subsequent testing, the tank is emptied fully and filled with sand by similar procedure.

\section{Methodology of test}

After the preparation of test bed, the model square footing of required size i.e., $50 \mathrm{~mm} \times 50 \mathrm{~mm}$ or $75 \mathrm{~mm} \times 75 \mathrm{~mm}$ is placed at centre of the test bed. Then the fabricated loading frame (loading platform) is placed centrally on the model square footing. The loading platform with its self-weight and the weight of the footing is only released which acted as the seating load as per IS 1888-1982. Then the shaft of the loading platform is arrested by locking screws. The dial gauges are fitted at the bottom surface of the loading platform to record the settlement of the footing. At the locked condition of the loading platform, the initial readings of the dial gauges are recorded. Then the locking screw of the loading platform is loosened carefully so that the load on the platform is transformed to the footing and thus the footing is allowed to settle under the load intensity. Settlement of the footing is recorded by dial gauges. After the stable of the footing (ensured by the no deflection of dial gauges), then next load is applied on the platform and record the settlement of the footing. The load test is continued till either the footing punched into the sand or the settlement exceeded to $0.2 \mathrm{~B} \mathrm{~mm}$. On completion of load test, the equipment are removed, the test tank is emptied and due preparations are made for the next set of load tests. A total of 32 numbers of load tests on model footings are conducted in the laboratory. Figure $2 \mathrm{~b}$ shows the photograph of experimental set up of load test and Fig. 2c shows the schematic view of experimental set up.

\section{Results and discussions}

When the reinforcement is placed in varying depth and size in sand bed, the settlement and ultimate bearing capacity has been changed due to effect of depth and size of reinforcement. So these are studied and discussed through Figs. 3, 4, 5, 6, 7, 8, 9, 10, 11, and 12. To quantify or compare the performance, the BCR defined as the ratio of bearing capacity with reinforcement to the bearing capacity without reinforcement are computed at a given rate of settlement. 


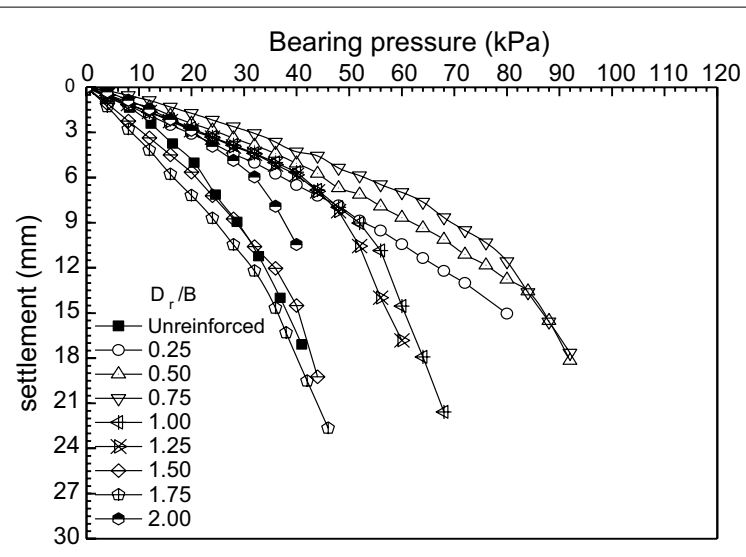

Fig. 4 Bearing pressure-settlement behavior of $75 \mathrm{~mm}$ square model footing on geojute reinforced sand

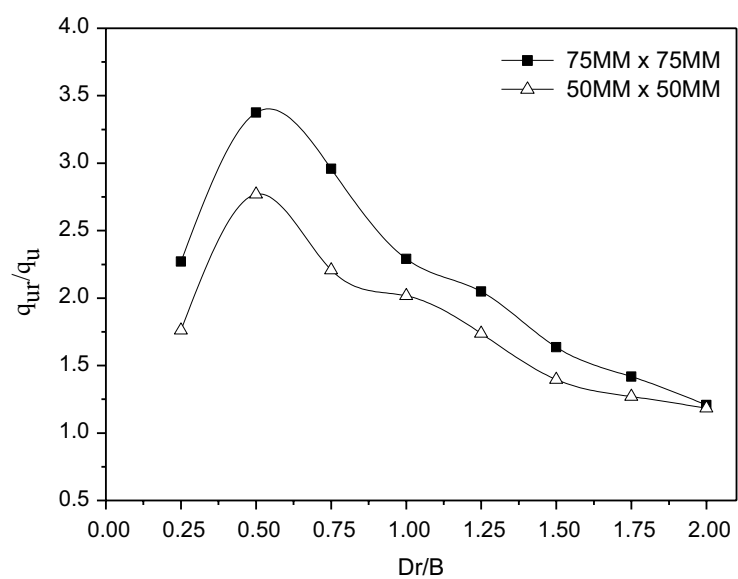

Fig. 5 Bearing capacity ratio vs Dr/B using geojute as reinforcement

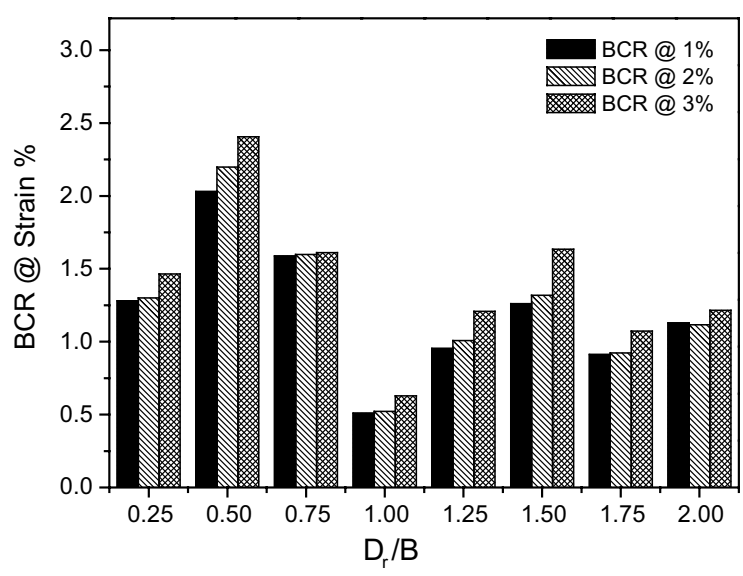

Fig. $6 \mathrm{BCR}$ of reinforced soil for 1, 2 and $3 \%$ strain for $50 \mathrm{~mm}$ square footing 


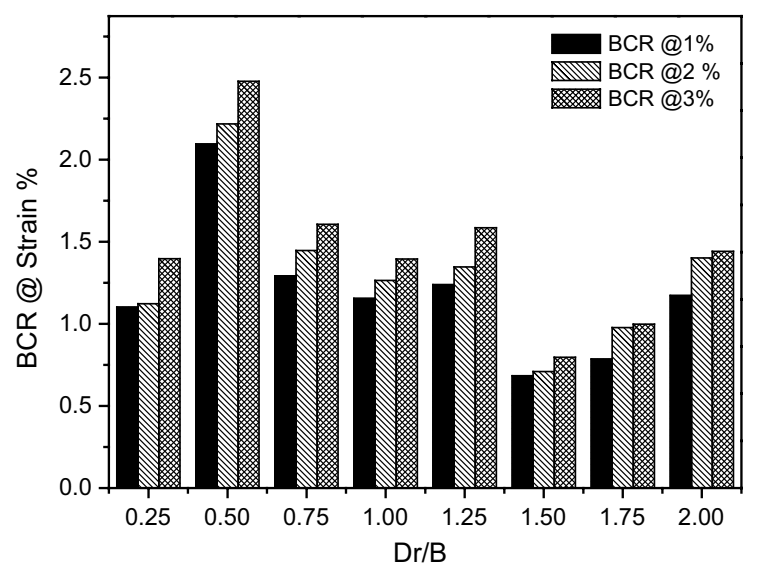

Fig. $7 \mathrm{BCR}$ of reinforced soil for 1,2 and $3 \%$ strain for $75 \mathrm{~mm}$ square footing

\section{Bearing pressure $(\mathrm{kPa})$}

$\begin{array}{lllllllllllllllll}0 & 5 & 10 & 15 & 20 & 25 & 30 & 35 & 40 & 45 & 50 & 55 & 60 & 65 & 70 & 75 & 80\end{array}$

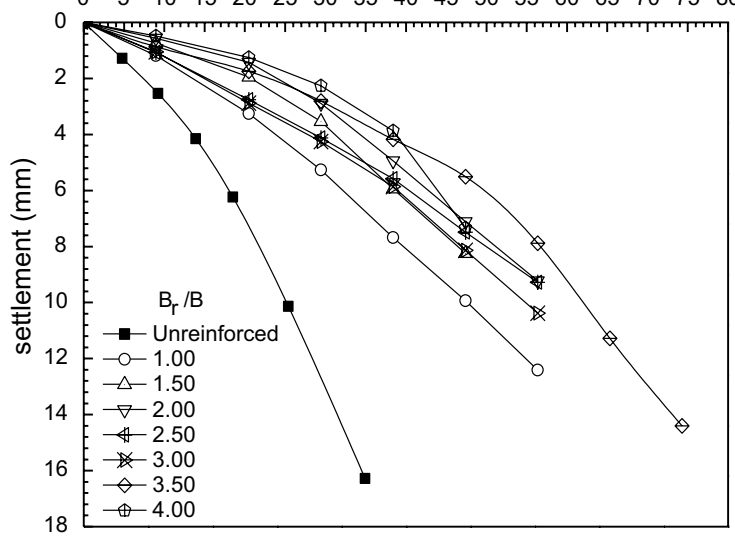

Fig. 8 Bearing pressure-settlement behavior of $50 \mathrm{~mm}$ square model footing on geojute reinforced sand (reinforcement depth ${ }^{\prime} \mathrm{D}_{r}^{\prime}=0.50 \mathrm{~B}$ )

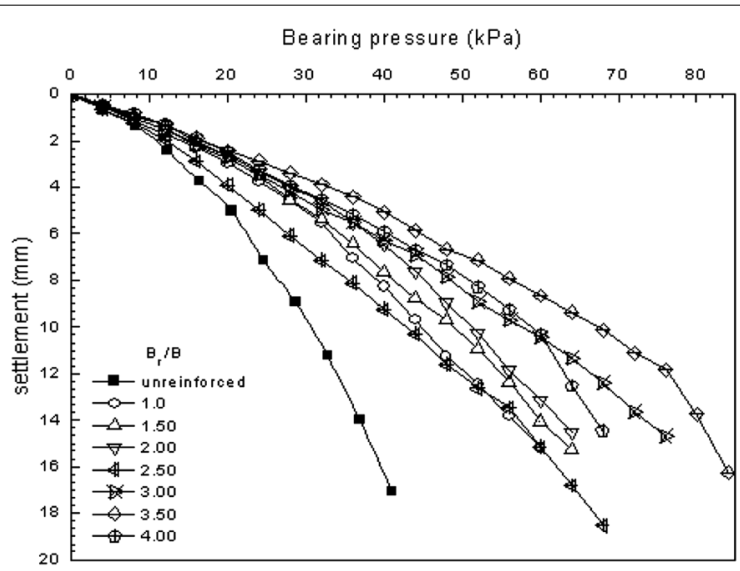

Fig. 9 Bearing pressure-settlement behavior of $75 \mathrm{~mm}$ square model footing on geojute reinforced sand (reinforcement depth ' $\mathrm{D}_{\mathrm{r}}{ }^{\prime}=0.50 \mathrm{~B}$ ) 


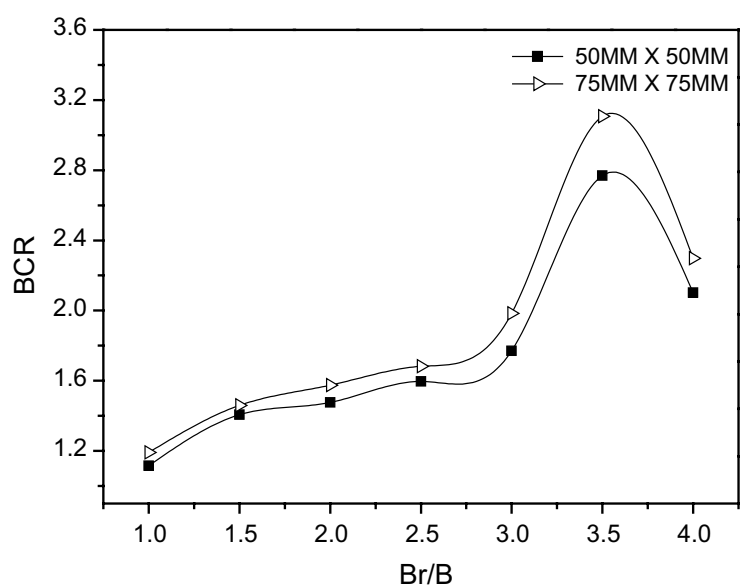

Fig. 10 Effect of size of reinforcement on the bearing capacity

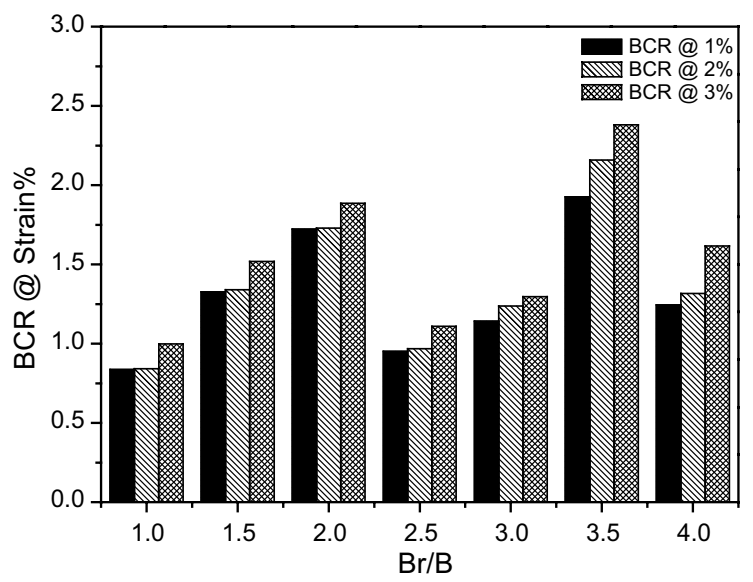

Fig. 11 BCR of reinforced soil for 1, 2 and $3 \%$ strain for $50 \mathrm{~mm}$ square footing with size of reinforcement $3.5 B$

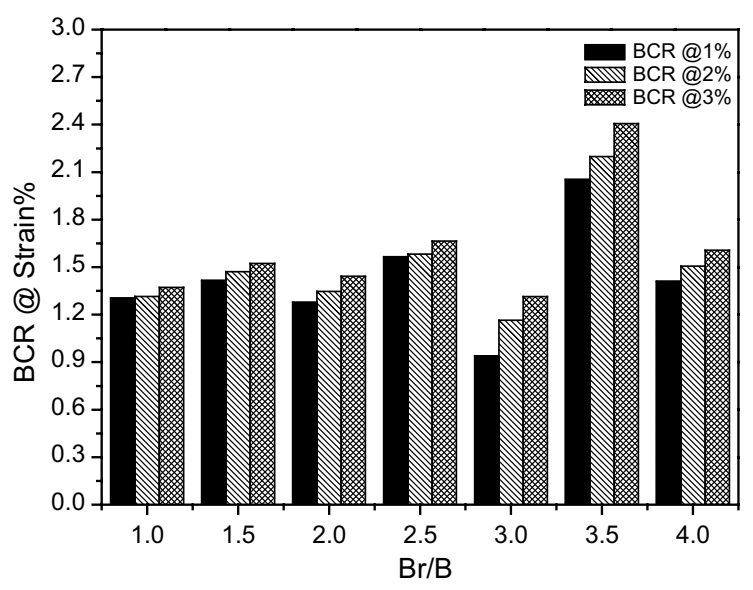

Fig. $12 B C R$ of reinforced soil for 1,2 and $3 \%$ strain for $75 \mathrm{~mm}$ square footing with size of reinforcement $3.5 B$ 


\section{Effect of depth of reinforcement}

The load-settlement behaviour of footings on reinforced sand at various depths of reinforcement i.e. $0.25 \mathrm{~B}$ to $2.00 \mathrm{~B}$ is compared with that of unreinforced sand. The results are reported in Figs. 3 and 4. The effect of bearing capacity ratio with respect to the depth of reinforcement is expressed in Fig. 5. It is observed that the bearing capacity ratio of reinforced soil is initially increased up to the depth $0.5 \mathrm{~B}$ and then gradually decreased with the increase of depth of reinforcement up to $2.0 \mathrm{~B}$. The most effective zone of reinforcement is observed in between $0.25 \mathrm{~B}$ and $0.75 \mathrm{~B}$ depth. So, $0.5 \mathrm{~B}$ is found to be as optimum depth. At the optimum depth of reinforcement, the UBC is increased by a factor 2.76 and 3.37 for $50 \mathrm{~mm}$ and $75 \mathrm{~mm}$ square footing respectively with geojute. The increase and decrease of bearing capacity ratio with respect to increase of depth may be due to the stress distribution theory. When a load is act on the foundation depth, the load is distributed within the influence zone of $2.0 \mathrm{~B}$ depth. The load intensity is high at the mid height of the influence zone i.e., 1.0B. But in the present study, the load intensity is high within the zone of $0.25 \mathrm{~B}$ to $0.75 \mathrm{~B}$ and obtained maximum value at $0.5 \mathrm{~B}$ by the application of reinforcement.

The BCR of reinforced soil (at different depth of reinforcement) for low strain ( $\mathrm{s} / \mathrm{B}=1$, 2 and 3\%) are presented in Figs. 6 and 7 for the footing $50 \mathrm{~mm}$ and $75 \mathrm{~mm}$ respectively. At optimum depth of reinforcement, the bearing capacity ratios of reinforced soil are improved by factors 2.03 to 2.40 and 2.09 to 2.47 for $50 \mathrm{~mm}$ and $75 \mathrm{~mm}$ square footing respectively when compared with the un-reinforced soil.

\section{Effect of size of reinforcement}

The load tests are also carried out at the optimum depth $(0.5 \mathrm{~B})$ of reinforcement by varying the size of reinforcement from $1.0 \mathrm{~B} \times 1.0 \mathrm{~B}$ to $4.0 \mathrm{~B} \times 4.0 \mathrm{~B}$. The results of the tests are presented in Figs. 8 and 9. The effect of size of reinforcement on the bearing capacity is expressed in Fig. 10. It is revealed that there is practically no gain in UBC when the size of reinforcement is equal to the size of footing. But, after that the UCB of reinforced soil increased with the increase of size of reinforcement up to $3.5 \mathrm{~B}$ and then decreased at 4.0B.

At low strain (i.e. $s / B=1,2$ and $3 \%$ ), the $B C R$ value of reinforced soil with the reinforcement depth $0.5 \mathrm{~B}$ is also studied and the results are presented in Figs. 11 and 12. It is revealed that the BCR of reinforced soils with reinforcement size $3.5 \mathrm{~B}$ are increased by the factors 1.92 to 2.38 for $50 \mathrm{~mm}$ square footing and 2.05 to 2.40 for $75 \mathrm{~mm}$ square footing when compared with the un-reinforced soil.

\section{Conclusion}

Total thirty-two model load tests are conducted to evaluate the potential of geotextile (geojute) for bearing capacity improvement. A single layer of geojute (for reinforcement) is placed beneath the $50 \mathrm{~mm}$ and $75 \mathrm{~mm}$ square footings in sandy soil. The ratio of depth of reinforcement to width of footing $(\mathrm{Dr} / \mathrm{B})$ is varied from 0.25 to 2. Also, the area of reinforcement is varied from $1 \mathrm{~B} \times 1 \mathrm{~B}$ to $4 \mathrm{~B} \times 4 \mathrm{~B}$. Based on the experimental results the following conclusions are drawn: 
1. The maximum gain in ultimate bearing capacity is observed when the reinforcement is placed at a depth of $0.5 \mathrm{~B}$.

2. The most effective zone of reinforcement lies between depths of $0.25 \mathrm{~B}$ to $0.75 \mathrm{~B}$.

3. At the optimum depth of reinforcement, UBC is increased by a factor 2.76 to 3.37 depending on footing size.

4. BCR also increased by a factor of 2.03 to 2.47 at low strains i.e. 1,2 and $3 \%$.

5. The optimum size of reinforcement is found to be $3.5 \mathrm{~B} \times 3.5 \mathrm{~B}$ irrespective of size of footing.

6. At optimum size and optimum depth of reinforcement, the UBC is increased by the factor of 2.7 to 3.6 when compared to the un-reinforced soil.

7. Hence, the geojute (natural geotextile) with size 3.5B (B is the width of footing) and at the depth of $0.5 \mathrm{~B}$ can be used to improve the bearing capacity of sandy soil.

\section{Authors' contributions}

BP and PKP carried out the present experimental investigation, compiled the results and drafted the manuscript. Both the authors read and approved the final manuscript.

\section{Competing interests}

The authors declare that they have no competing interests.

Received: 1 February 2018 Accepted: 4 September 2019

Published online: 11 September 2019

\section{References}

1. Adams MT, Collin JG (1997) Large model spread footing load tests on geosynthetic reinforced soil foundations. J Geotech Eng 123(1):66-72

2. Akinmusuru JO, Akinbolade JA (1981) Stability of loaded footings on reinforced soil. J Geotech Eng 107(6):819-827

3. Banerjee PK, Ghosh M (2008) Studies on jute-asphalt composites. J Appl Polym Sci 109(5):3165-3172

4. Binquet J, Lee KL (1975) Bearing capacity tests on reinforced earth slabs. J Geotech Eng 101(12):1241-1255

5. Binquet J, Lee KL (1975) Bearing capacity tests on reinforced earth slabs. J Geotech Eng 101(12):1257-1276

6. Bureau of Indian Standards: (a) IS 1498: 1970_Classification and identification of soils for general engineering purposes. (b) IS 2720 (Part-2): 1973-Methods of test for soils: Determination of water content. (c) IS 2720 (Part-13): 1986_Methods of test for soils: Direct shear test. (d) IS 2720 (Part-14): 1983—Methods of test for soils: Determination of density index relative density of cohesionless soils. (e) IS 6403: 1981_Code of practice for determination of bearing capacity of shallow foundations. (f) IS 1888: 1982 - Method of load test on soils

7. Cao Y, Shibata S, Fukumoto I (2006) Mechanical properties of biodegradable composites reinforced with bagasse fibre before and after alkali treatments. Appl Sci Manuf 37:423-429

8. Chakrabarty S, Bhandari G, Adak N (1997) Performance of model footing on compacted PFA, geojute reinforcement overlaying soft clay. In: Workshop on jute geotextiles, organised by IJMA \& JMDC, Kolkata

9. Chakrabarti S, Bhandari G, Datta A (2002) Biodegradation effect of jute geotextile as soil reinforcement for improvement of load-settlement characteristics. In: Proceedings of IGC 2002, held during December 20-22, 2002, at Allahabad, vol I, pp 187-190

10. Datta A (1998) An experimental study on the effect of degradation of geojute on load-settlement behaviour of soft soil through model test. MCE Thesis submitted to Jadavpur University, Kolkata

11. Dash SK, Rajagopal K, Krishnaswamy NR (2001) Strip footing on geocell reinforced sand beds with additional planner reinforcement. J Geo Textiles Geo Membr 19(8):529-538

12. Farsakh et al (2013) An experimental evolution of the behaviour of square footings on reinforced sand. Japn Geotech Soc Soils Found 53(2):335-348

13. Fragaszy RJ, Lawton E (1984) Bearing capacity of reinforced sand sub grades. J Geotech Eng Div 110(10):1500-1507

14. Ghazavi M, Lavasan AA (2008) Interference effect of shallow foundations constructed on sand reinforced with geosynthetics. Geotext Geomembr 26(5):404-415

15. Huang CC, Tatsuoka F (1990) Bearing capacity of reinforced horizontal sandy ground. J Geotextiles Geomembr 9(1):51-82

16. Jadhav SP, Damgir RM (2011) Use of jute geo textile for strengthening of sub grade of road work. Government College of Engineering Aurangabad, Maharashtra

17. Khing KH, Das BM, Puri VK, Cook EE, Yen SC (1993) The bearing capacity of a strip foundation on geogrid-reinforced sand. Geotext Geomembr 12(4):351-361 
18. Kumar A, Kaur A (2012) Model test of square footing resting on fibre-reinforced sand bed. Geosynth Int 19(5):385-392

19. Latha GM, Somwanshi A (2009) Bearing capacity of square footings on geo synthetic reinforced sand. Geotextile Geomembr 27:281-294

20. Lavasan AA, Ghazavi M (2012) Behaviour of closely spaced square and circular footings on reinforced sand. Japn Geotech Soc Soils Found 52:160-167

21. Macaulay MO (2014) The effects of alkali treatment on the mechanical properties of jute fabric reinforced epoxy composite. Int J Fiber Textile Res (IJFTR). 4(2):32-40

22. Omar MT, Das BM, Puri VK, Yen SC (1993) Ultimate bearing capacity of shallow foundations on sand with geo grid reinforcement. Can Geotech J 30:545-549

23. Patra CR, Das BM, Atalar C (2005) Bearing capacity of embedded strip foundation on geogrid-reinforced sand. Geotext Geomembr 23:454-462

24. Ranganathan SR (1994) Development and potential of jute geotextiles. Geotextiles Geomembr 13(6-7):421-434

25. Rao GV, Balan K (1996) Durability of Jute Fabric. In: International seminar and technomeet on "environmental geotechnology with geosynthetics", New Delhi

26. Rao PJ, Bindumadhava, Vensiri M (2003) Construction of highway embankment on soft marine soil using jute geotextiles. In: National seminar on "application of jute geotextile \& innovative jute products", New Delhi

27. Ronad (2014) An experimental study of square footings resting on geogrid reinforced sand. IJERT 03:177-181

28. Rong MZ, Zhang MQ, Liu Y, Yang GC, Zeng HM (2001) The effect of fibre treatment on the mechanical properties of unidirectional sisal reinforced epoxy composites. Compos Sci Technol 61:1437-1447

29. Rout J, Misra M, Tripathy SS, Nayak SK, Mohanty AK (2001) The influence of fibre treatment on the performance of coir-polyester composites. Compos Sci Technol 61:1303-1310

30. Sahu RB, Hazra HK, Som N (2006) A laboratory study on geojute Reinforced soil bed under cyclic loading — published in National Jute Board (Jute Manufactures Development Council)

31. Shin EC, Das BM (2000) Experimental study of bearing capacity of a strip foundation on geogrid-reinforced sand Geosynth Int 7(1):59-71

32. Sitharam TG, Sireesh S (2004) Model studies of embedded circular footing on geogrid reinforced sand beds. Ground Improvement 8(2):69-75

33. Vidal H (1966) La terre Armée. Annales de l'Institut Technique de Batiment et de Travaux Publics No.223, France

34. Yetimoglu T, Wu JTH, Saglamer A (1994) Bearing capacity of rectangular footings on geogrid-reinforced sand. J Geotech Eng ASCE 120(12):2083-2099

\section{Publisher's Note}

Springer Nature remains neutral with regard to jurisdictional claims in published maps and institutional affiliations.

\section{Submit your manuscript to a SpringerOpen ${ }^{\circ}$ journal and benefit from:}

- Convenient online submission

- Rigorous peer review

- Open access: articles freely available online

- High visibility within the field

- Retaining the copyright to your article

Submit your next manuscript at $\boldsymbol{\Delta}$ springeropen.com 